Published in The Journal of Blacks in Higher Education 35:102-106 (Spring 2002)

Copyright 2002 by Jack M. Balkin. All rights reserved.

\title{
Would African-Americans Have Been Better Off Without Brown v. Board of Education?
}

Jack M. Balkin

Suppose that the United States Supreme Court had reaffirmed Plessy v. Ferguson in Brown v. Board of Education and strictly enforced its separate but equal doctrine. What would have been the subsequent history of educational opportunity for African-Americans? Charles Hamilton Houston's original strategy was to persuade courts to enforce Plessy strictly, assuming that southern states would not be able to afford a truly separate but equal school system. If southern states wanted quality education for their white children they would be forced to integrate to save money. So it is interesting to speculate whether African American children would have been better off with strict enforcement of Plessy. Perhaps black parents might have gotten integrated schools anyway, or if not integrated schools, then equal schools.

Remedies under Plessy would not have required courts to bus school children. Without court ordered busing, politicians in both the North and South might not have been able to whip up the same degree of racial resentment. If so, the movement for equalization of schools and systems of school finance might not have become so deeply racialized. The Supreme Court might have decided the Rodriguez case differently-- finding a federal constitutional right of equal educational opportunity-- or perhaps school equalization suits in the states might have made greater headway. Conceivably the policy debate would have been less about race and more about class, and African American children would be better off as a result. In addition, if states chose equalization instead of integration, a generation of black principals and schoolteachers might not have been displaced, and this might have benefitted the black community as a whole. Finally, if the courts refrained from directly overrulling Plessy, the movement for racial equality and equal opportunity would more clearly have seemed to come from Congress and the political branches rather than from the courts. This would make civil rights seem more democratic and less an imposition on democracy by judicial elites.

Nevertheless, I am skeptical that things would have turned out very differently if the Court had reaffirmed Plessy's doctrine of separate but equal in 1954. In answering this question an important preliminary issue is how the change would have affected the fate of the civil rights movement. There are good reasons to think that reaffirming separate but equal would not necessarily have derailed the movement. Even before Brown was decided, the Baton Rouge boycott had occurred. The civil rights movement would have proceeded apace without the Brown we know today, and conceivably with less southern white resistance. After all, the decision in Brown polarized public opinion, stiffened white southern resistance and put southern white racial moderates in a politically difficult position. Of course, this cuts both ways, for one could argue that southern intransigence actually aided the civil rights movement by arousing northern sympathies. Nevertheless, it is difficult to maintain that by itself hatred of Brown perversely guaranteed the success of the civil rights movement. It was only one factor among many. This suggests that even had the Court pushed for strict equalization instead of overruling Plessy, there eventually would have been federal civil rights legislation, although it might not 
have occurred precisely when it did. Moreover, in both scenarios, civil rights legislation would probably have done more to promote racial equality than any court decision. Recall that Brown itself was not very successfully enforced in the South until Congress passed Title VI of the Civil Rights Act of 1964, which threatened southern schools with financial penalties for continued intransigence.

Indeed, it is entirely possible that if the civil rights movement had succeeded without Brown, and if Congress had passed something like the 1964 Civil Rights Act, and the 1965 Voting Rights Act, the Court soon would have followed the political tides and overruled Plessy, perhaps at most a decade or so after it actually did. Put another way, a successful social movement would have eventually doomed Jim Crow anyway-- the only question is whether the courts or the political branches would have moved first.

However, even if blacks would not have been much worse off under a continued regime of separate but equal, it does not follow that they would have been better off. It is important to recall that strict enforcement of Plessy did not require actual equality in educational opportunity. Plessy merely presented an either/or proposition. If the states segregated by law, they had to make facilities equal. But if states did not segregate by law, Plessy did not require equalization of facilities. That meant that in the North, where school segregation was not mandated by law, Plessy was virtually useless in guaranteeing equal educational opportunity for African Americans. In the South, many school districts might have moved to freedom of choice plans (as they did in the years after Brown), which were nominally race neutral but which would have escaped Plessy's requirement of equal funding and equal facilities. It would have been relatively easy for southern school districts to argue that their school systems were not formally "separate" (even if they were so in fact) if that would relieve them from equalization responsibilities. Indeed, as cities and suburbs grew in the 1950s, 1960s and 1970s, strict promotion of neighborhood school policies would have produced largely segregated public schools without any constitutional requirement of equal funding or equal facilities. In this respect, the result would have been much the same as actually occurred. The only difference is that there would be no available constitutional argument (along the lines of the Court's 1968 decision in Green v. New Kent County School Board) that racially identifiable schools violated the Constitution. So white flight to suburbs would probably still have occurred, and because minority schools in inner cities would be de facto rather than de jure segregated, there would be no constitutionally mandated equalization requirement. Under this line of reasoning, strict enforcement of Plessy would have done blacks little good because the decision would have been even easier to get around than the relatively toothless enforcement of Brown itself.

Indeed, retaining Plessy might have left blacks worse off. Much school segregation occurred because of residential segregation produced by the racially discriminatory housing and real estate policies of private parties, state and local officials, and the federal government. Many of the policies of state actors were technically illegal under Brown and later cases, but the laws were systematically underenforced or narrowly construed. If Plessy had not been overruled, then presumably there would have been even less protection against racial discrimination in housing policies, and therefore the effect of housing segregation on school segregation would have been, if anything, even more pronounced. To be sure, Congress might still have passed federal housing discrimination legislation in the late 1960's, but there is no reason to think that it would be more strictly or fairly enforced if Plessy had been retained.

Social forces in both the North and South sought to maintain white racial privilege and 
material benefits in the face of increasingly strident demands by African-Americans in the 1950s and 1960s. Those social forces in defense of white privilege would probably have been just as strong whether the doctrinal forms were those mandated by Plessy or those mandated by Brown. In either case whites would have attempted to preserve as much as possible and sought practical end runs around the formal legal regime. It is therefore not surprising that the results would have been the same in many respects.

The key issue is how legal doctrines interact with social norms. In general, legal doctrines are most efficacious when they are powerfully supported by social norms, are difficult to circumvent, and cannot easily be watered down or evaded by disputes over their interpretation or meaning. Conversely, legal doctrines are least efficacious when they move against the tide of social norms, when there are fairly easy ways to get around them, and when they are relatively abstract or underdetermined. This suggests that the choice between the actual decision in Brown or strict enforcement of Plessy's "separate but equal" formula would not have made much difference. If Brown was easy to evade, so too would have been a reenergized doctrine of "separate but equal." Even before Brown, southern judges and lawyers for segregated southern school districts had little difficulty manipulating factual records to conclude that black and white schools were "substantially" equal. Nor would strict enforcement of Plessy have gained much social support. During the 1950's much of the country outside the South- and particularly opinion elites-- increasingly thought of Jim Crow as an embarrassment, but the country did not particularly support integration or redistribution of substantial amounts of income or resources to African Americans. And of course, in the deep South there was strong attachment to the racial status quo. That racial status quo had both symbolic and material elements-- it involved not only segregation of the races but also preservation of material advantages for whites. Thus, it is tempting but overly optimistic to assume that whites would have been happy to fund black schools equally as long as their children did not have to share classrooms with black students.

Ultimately the question is not whether the courts did the right thing in overturning Plessy in 1954. The question is whether the American people did the right thing in responding to the civil rights movement and passing civil rights legislation during the 1960's. They did do the right thing, but there is a lot more that they could have done, and a lot more that they still could do.

Jack M. Balkin is Knight Professor of Constitutional Law and the First Amendment at Yale Law School. His most recent book is "What Brown v. Board of Education Should Have Said" (NYU Press 2001). 